Article

\title{
Existentialism, Epiphany, and Polyphony in Dostoevsky's Post-Siberian Novels
}

\author{
Bilal Siddiqi \\ SSEES, University College London, London WC1H 0BW, UK; tjmsidd@ucl.ac.uk
}

Received: 3 December 2018; Accepted: 11 January 2019; Published: 17 January 2019

\begin{abstract}
Dostoevsky can be meaningfully read as a defender of Russian Orthodoxy; a psychologist; a polemicizing anti-nihilist ideologue; a Schillerian romantic; a Solovyovian believer in love, goodness, and beauty; a prophet. I approach Dostoevsky through a new lens-Dostoevsky as an existential phenomenologist. Although writers such as Kauffman, Camus, and Shestov have cast Dostoevsky as an existentialist, their readings often focus too heavily on the critique of rationalist thinking in Dostoevsky's The Underground Man and explore Dostoevsky's existentialism largely in ethical rather than in existential-ontological terms. My interpretation will instead demonstrate that the primary focus of Dostoevsky's novels is on immanent existential-ontological truths-human life-rather than on transcendental, ideal truth, although the emphasis on the former does not negate the possible existence of the latter. This interpretation will also provide an original route towards a polyphonic reading of Dostoevsky.
\end{abstract}

Keywords: Dostoevsky; Russian Literature; existentialism; epiphany; polyphony

This article argues that Dostoevsky is an existential phenomenologist and interpreting him as such provides a new route towards a polyphonic reading of Dostoevsky. It demonstrates that the primary focus of Dostoevsky's novels is on immanent existential-ontological truths-human life-rather than on transcendental, ideal truth, although the emphasis on the former does not negate the possible existence of the latter.

Existential phenomenology is defined as the process of cataloguing ways in which humans can primordially experience the constitutive features that form the conditions of the possibility of human experience, what Heidegger calls 'existentialia' (Heidegger 2007, pp. 69-71). These primordial experiences occur in moments of 'epiphany'.

Epiphany is an underexplored, yet crucial concept for understanding Dostoevsky's fiction as well as his personal spiritual journey. ${ }^{1}$ In the novels, moments of epiphany often represent a primordial experience of a particular necessary condition for the possibility of human experience-an 'existentiale'. A glance at Dostoevsky's major novels shows how these moments illuminate radically different existentialia. For example, Stepan Verkhovensky and Shatov in Demons, Alyosha in Brothers Karamazov or Myshkin in The Idiot all experience reflexive forms of being-with (Heidegger 2007, sct. 26), a mode conspicuously neglected by Heidegger's Being and Time, but given fuller expression by Bakhtin in Towards the Philosophy of the Act and Levinas in Totality and Infinity (Bakhtin 1993, p. 64; Lévinas 1969, p. 215). Ivan Karamazov and Stavrogin both experience attacks of 'conscience' in their hallucinations, while characters

1 Dostoevsky's 'vision of the peasant Marei' is a famous biographical epiphany that the author recounts later in life in his journal, A Writer's Diary (Dostoevsky 1994, pp. 351-55). The vision is actually a memory from his childhood. Dostoevsky, while playing outdoors, believes he has seen a wolf and is frightened. The peasant Marei offered him maternal and spiritual comfort, which put him at ease. Dostoevsky claims that he suddenly evoked this memory vividly during his imprisonment in Siberia, and it provided him with solace. This episode, as well as Dostoevsky's well-documented aural epileptic episodes, indicates that epiphanic experience played a significant role in Dostoevsky's own spiritual journey as well as those of his fictional characters. 
in Demons experience varied relations to their own mortality, with Kirillov experiencing the primordial nullity of death (Heidegger 2007, sct. 54). In brief, characters transpose the meaning of a particular necessary existential relation to the world (being-with; being-towards-death; conscience; mood) into lived experience during epiphanic moments. Taking these moments together will demonstrate how Dostoevsky's novels are primarily concerned with understanding human nature in its immanence and finitude. In this article, I have chosen to focus on the epiphanies of Stavrogin and Kirillov from Demons and Alyosha from Brothers Karamazov. Stavrogin and Kirillov, who are closely connected to one another in Demons, provide symmetry through their contrasting epiphanic experiences, as the former struggles to come to grips with the nullity of his own birth, whereas the latter seeks to stretch forward to an experience of his death, marking Dostoevsky's existentialism as concerned with understanding human life, as it is always and necessarily, reaching out from the space between birth and death. Alyosha was an obvious choice as the 'Cana of Galilee' episode is one of the most famous epiphanies in Dostoevsky, and provides a route to understanding the ontological basis for the primary ethical meaning in Dostoevsky's novels.

Although the term 'epiphany' has strong religious associations, these are not in play in all such primordial experiences in the novels. However, in the course of the essay, I associate these characters' varied experiences with themes such as transcendence, timelessness, and guilt, which are central to monotheistic religious traditions. Even if such epiphanies do not establish the actuality and truth of transcendence, they may do enough to establish its possibility as a necessary horizon of human existence.

\section{Dostoevsky's 'Existentialism'}

Early existentialist readings of Dostoevsky focused on Notes from Underground (Kaufmann 2004). The underground man's insistence that man is not an 'organ stop' (Dostoevsky 2001, p. 23) or Dmitry Karamazov's exclamation that 'man is not a drum!' (Dostoevsky 2003a, p. 615) provide insight into Dostoevsky's insistence on the intrinsic and sacred value of personhood and freedom. However, the underground man is a nihilist who is incapable of loving anyone, including himself. In Winter Notes on Summer Impressions, Dostoevsky makes clear that western rationalism, rooted in the value of the individual, as opposed to society, can never lead to true brotherhood. For him brotherhood or voluntary sacrifice of one's own personal interests for the sake of all, as exemplified by Christ, is the only route to highest personhood (Dostoevsky 1997, pp. 48-49). In light of this, Lev Shestov's attempt to read Dostoevsky biographically as someone seeking a Nietzschian 'revaluation of all values' largely based on the views of one of his deeply individualist characters-the underground man-does not ring true biographically (Shestov 1969, p. 202). I argue that the deeper thread of Dostoevsky's existentialism does not live on the ethical plane, in the 'revaluation of all values' as Shestov states, but on the existential-ontological plane.

Dostoevsky's existentialism, rather, can be encapsulated in one of Heidegger's fundamental philosophical assumptions, 'The essence of Dasein lies in its existence' (Heidegger 2007, p. 67). We can take Dasein to refer to 'human being', although this is not faithful to Heidegger's use of the term. ${ }^{2}$ The phrase therefore reads as 'The essence of human beings lies in their existence'.

If I ask, 'what is a human being?' I may arrive at a definition of a human as a bipedal mammal, or as homo sapiens, a distinct species within the animal kingdom. This provides an 'essential' —anatomical or biological—categorical definition of humans. But does this reveal what it means to be human? For existentialists, the question is not 'what?' a human being is, but about the way in which he/she is. The dictum 'The essence of Dasein lies in its existence' means that existence, a lived relation to the

2 Heidegger uses the term Dasein partially to critique Cartesian subjectivity as well as to indicate the fundamental and determinative layer of human life he is giving attention to-namely existential life. 'Da' (there) 'sein' (being) instead of referring to the cogito or ' $\mathrm{I}$ '- the thinking 'subject' of idealist philosophy-refers to a being 'there' affected by and immersed in the world (Heidegger 2007, pp. 27, 46). Since I intend to make no further direct reference to this distinction, I have chosen, for simplicity's sake, to use the traditional term, 'human being' instead of Dasein in most cases. 
world, precedes, grounds, and makes possible any essential, categorical understanding of man as an abstract entity or a being corresponding to some ideal form (Ibid., p. 88). Therefore, the essence of human reality is not the atom, or the molecule, or pure rationality, not ideal form, harmony, or beauty, but lived experience. This is the defining principle for 'existentialism'.

Several prominent commentators have recognized this existential impulse running through Dostoevsky's work. Berdyaev noted that Dostoevsky, "was anthropological and anthropocentric to an almost inexpressible degree: the problem of man was his absorbing passion" (Berdyaev 1957, p. 39). For Berdyaev, as for Bakhtin, everything in Dostoevsky is invested into human nature. Jackson also notes that Dostoevsky presents an existential view of human reality where truth can only be apprehended in the movement and struggle of existence (Jackson 1978, Preface p. xi). Of all Dostoevsky commentators, Bakhtin comes closest to recognizing Dostoevsky's existentialism.

For Bakhtin, Dostoevsky was primarily concerned with "revealing personality in actual life ..." (Bakhtin 1984, p. 12). Truth is a lived experience of the meaningful rather than an impersonal, unchanging utterance or ideal. Bakhtin's Dostoevsky comes close to mirroring Heidegger's fundamental proposition. With Dostoevsky's characters, "We see not who he is, but how he is conscious of himself; our act of artistic visualization occurs not before the reality of the hero, but before a pure function of his awareness of that reality" (Ibid., p. 49). As stated earlier, we ought not to ask 'what' a human being is, but the way in which he/she is. For Bakhtin, Dostoevsky's characters embody this same ethic, and to understand them is to understand how they are conscious of themselves.

\section{Epiphany}

The 'deepest layers' (Ibid., p. 157) of human life are revealed in Dostoevsky's novels in moments of epiphany. 'Epiphany', derived from the Greek epiphainesthai, meaning to 'appear' or 'come into view', refers to moments of sudden and significant insight (McDonald 2008, p. 91).

William James identifies the key characteristics of what I term 'epiphanic' and what he terms 'mystical' experiences in The Varieties of Religious Experience. ${ }^{3}$ They include ineffability, transiency, passivity, and noetic quality (James 1982, pp. 380-81). The experience is 'ineffable' in that it is difficult to articulate. This quality makes these experiences 'more like states of feeling' (Ibid.) than theoretical knowledge. Epiphanies are 'transient'; they are passing sensations. They involve 'passivity', which means that during the experience one feels held 'by a superior power' (Ibid.), thus including experiences such as 'prophetic speech, automatic writing, or the mediumistic trance' (Ibid.). 'Noetic Quality' means that the experience provides some insight; it signifies a revelation of new primordial knowledge.

The present article focusses on 'ecstatic' epiphanies. This term signifies a state where one is in the grips of powerful and overwhelming forces. The subject is taken out of him/herself, as in the Greek ekstasis ( $\check{\kappa} \kappa \tau \tau \sigma \sigma \iota \varsigma)$. Although there are a range of different forms of epiphany in Dostoevsky, 'ecstatic' epiphanies are the most semantically varied, and indicate contact with primordial truths. The overt symptoms of such experiences can be correlated with James' traits of mystical experiences.

Bakhtin and Jackson each find a place for what I call 'ecstatic epiphanies'. For Bakhtin, such epiphanies are a type of 'threshold moment' (Bakhtin 1984, pp. 116-17). "Dostoevsky always represents a person on the threshold of a final decision, at a moment of crisis, at an unfinalizable-and unpredeterminable - turning point for his soul" (Ibid.). An epiphany can be regarded as a "moment of crisis' and a 'turning point in the soul'. 'Ecstatic epiphanies', insofar as they take the person out of themselves, fit Bakhtin's description of time on the threshold as 'life taken out of life' (Ibid., p. 172). Bakhtin roots the 'epiphanic' in menippean satire (Ibid., pp. 116-17). He notes that dreams, daydreams,

3 This statement may raise the question - what is the difference between epiphanies and mystical experiences? However, this question is largely a theological one and beyond the remit of this article. I can provisionally state, largely through inferences drawn from James, Smart, and Lossky's book on mysticism in the Eastern Orthodox Church, that it amounts to the difference between 'process' (mysticism) and 'moment' (epiphany) (Smart 1984; Lossky 2005). 
insanity, split personalities, passions bordering on madness are all visible in menippean satire, where they 'permit us to look at a person in a new way' (Ibid., p. 117), and that Dostoevsky's novels contain 'all of the defining features of the menippea', albeit in more complicated form (Ibid., p. 121). For Jackson, 'revelation', a corollary of epiphany, has fundamental significance in Dostoevsky. 'The highest perception of beauty is revelation' (Jackson 1978, p. 52). Myshkin's aural epiphanic episode gives him a revelation of measure, proportion, harmony, which constitutes the highest perception of beauty.

Although Jackson recognizes the significance of moments of revelation in Dostoevsky, these moments ultimately reveal a single overarching existential truth for him: human striving for ideal form and beauty (Ibid., pp. 134-35). Even though this quest takes place within a contingent world of chaos and formlessness, it still univocally aims at the ethical image of Christ. Thus, Dmitry and Myshkin's revelations are Jackson's ideal examples of the process of revelation and transfiguration.

For Bakhtin, by contrast, the sense of the carnival in literature, and the threshold moments they give rise to, allow latent aspects of human nature to reveal themselves (Bakhtin 1984, p. 123). Thus, there is room for polyphonic revelation in threshold moments. However, Bakhtin's interest in Dostoevsky stretches only to the metalinguistic conditions that make such polyphonic revelation possible. "But what interests us here is not those depths of life that Dostoevsky glimpsed, but only the form of their visualization, and the role played in that form by elements of carnivalization" (Ibid., p. 174). The moments do not all aim at the same ideal of harmony, beauty, and goodness. Nor do they all principally indicate the same truth about our dialogic relation to others. Instead, they reveal different, but simultaneously necessary conditions for the possibility of human experience.

A study of these moments will demonstrate Dostoevsky's novels' emphasis on immanent existence. The novels seek to understand human beings as they are in the world and not from an ideal, transcendent perspective that finalizes them. Taken together, these epiphanies reveal truths about the human condition as it necessarily must be in the space between birth and death.

\section{Stavrogin}

Stavrogin is the philosophical and spiritual centre of Dostoevsky's novel, Demons (Dostoevsky 1968, p. 26). An elusive character whose connection to the main plot of the novel remains nebulous, he engages in significant dialogic exchanges with other characters, notably Kirillov, Shatov, Dasha, Tikhon and the younger Verkhovensky; all the while seeking some idea to believe in. He ultimately commits suicide.

Stavrogin's epiphany appears in a written confession in the censored chapter, 'At Tikhon's'. J.M Coetzee and Malcolm Jones have both problematized the motives for Stavrogin's confession, comparing it to a similar episode in Rousseau's Confessions. Both argue that Stavrogin's is not really a confessional text because it is not faithful to the idea of overcoming 'guilt and shame in the name of the truth' (Jones 1983, pp. 83-84; Coetzee 1985, p. 230). Malcolm Jones recognizes that Stavrogin gains a perverse kind of pleasure from his attacks of guilty conscience (Jones 1983, p. 88). In Dostoevsky's notebooks, Stavrogin has a 'passion for the pangs of conscience' (Dostoevsky 1968, p. 371) and in the novel, "Is this what is called pangs of conscience or repentance? [ ... ] Perhaps even to this very day I don't find the memory of what I did loathsome, perhaps even now this memory contains something that gratifies my passion" (Dostoevsky 2008, p. 776). Stavrogin's perverse enjoyment of his guilt challenges Joseph Frank's notion that he is sincerely seeking self-submission, or "to attain a state of genuine humility" (Frank 1969, p. 670).

Stavrogin's epiphany contains two separate visions-a utopian dream and a haunting hallucination. Hallucinations are a constant underlying presence for him (Dostoevsky 2008, pp. 325, 744). In his confession, he describes the first appearance of his most persistent apparition-a vision of Matryosha. It first appears after Matryosha, an innocent child who he rapes, has killed herself. He claims that the moment occurred 'about a year ago' when he had fallen asleep after a long spell of travelling. 
Before the Matryosha hallucination, he dreams of a glorious utopia inspired by Claude Lorrain's painting, 'Acis and Galatea', which he calls 'The Golden Age'. Stavrogin considers this painting to represent an origin-myth-'what the people of Europe remembered as their cradle' (Ibid., p. 775). It strikes him as profound and produces overwhelming happiness. He awakens and wishes to go back to sleep, but before he can do so, 'a tiny red spider' appears to him. He raises himself up on his bed and sees a hallucinated vision of a silently commanding, remonstrative Matryosha, " [ . . ] shaking her head and brandishing her tiny little fist at me" (Ibid., p. 776).

Richard Peace recognizes the significance of the vision of 'The Golden Age' in Dostoevsky's works, and mentions that Stavrogin's dream may be connected to a sense of inner guilt. However, he makes no mention of Matryosha and does not connect the two visions (Peace 1971, p. 62). By contrast, two commentaries connect them. Rollberg (2014, p. 150) claims that the 'complementary nature of the confession has never been adequately addressed in literary criticism' and interprets the doubled epiphany as reflecting the high and low aspects of Stavrogin. Stavrogin behaves in a contemptuous and arrogant manner towards others because he 'carries in him an ideal of a perfect world' (Ibid.) whose standards of virtue people fail to match in life. Anderson sees the two visions as connected insofar as in the first, 'Stavrogin had for a moment recaptured his innocence' (Anderson 1997, pp. 108-9) but the subsequent vision of Matryosha reminds him of how he robbed another of their innocence. The vision becomes a call to genuine repentance, though Anderson recognizes that Stavrogin ultimately rejects this call (Ibid., p. 115). I argue, however, that Stavrogin does not 'recaptures his innocence' in his dream, even momentarily. Stavrogin cannot believe in the origin myth he dreams of, since it is an origin that he did not himself will and is irrevocably severed from. The subsequent vision of Matryosha serves as a warning, revealing to him the limitations of his will. This is what I intend to propose in more detail in this section.

Malcolm Jones has presented the Matryosha scene as an example of 'gratuitous victimization' (Jones 1983, p. 82) but, unlike in Rousseau, Dostoevsky's scene allows us to see the impact of Stavrogin's victimization on the innocent victim, Matryosha, as well. Coetzee interprets Stavrogin's actions towards the girl as motivated by a desire to seek 'measureless suffering' (Coetzee 1985, p. 229). There is significant truth to both these notions, though why Stavrogin seeks 'measureless suffering' has not become apparent.

What then does Stavrogin truly seek? I would argue the answer is 'self-mastery'. During his confession to Tikhon, he repeatedly emphasizes that he always chose to act in a perverse or cruel and rapacious manner. Although he recognizes that he cannot live with his vision of Matryosha, at the same time, he wants to believe that he can.

'I could dismiss this little girl from my mind even now, whenever I feel like it. I have full mastery of my will, as before. But the whole point is that I never wanted to do so [ ... ] and so it will continue right up to the point where I lose my mind'. (Dostoevsky 2008, p. 777)

Stavrogin denies the pain of guilt he feels at his horrific crime, because he desires to be his own basis. Speaking in Dostoevsky's notebooks, he claim to lives for himself and states his ambition of separation from others: 'I want to be above all movements and vacillations: I'm all alone and I live for myself' (Dostoevsky 1968, p. 81). As Bakhtin notes, Stavrogin suffers from a 'vicious circle [... ] he fears that the other might think he fears that other's opinion' (Bakhtin 1984, p. 229). ${ }^{4}$ He attempts to shake off his dependence on the other's voice, but is unable to be at peace with himself. His desire to refute the other, 'confirms precisely what he wishes to refute, and he knows it' (Ibid.). In service of a deluded ambition towards exclusive self-mastery, Stavrogin refuses every external force acting upon him.

Stavrogin's dream is partly a manifestation of this ambition. Frank recognizes that Stavrogin is the thematic centre and ideological progenitor of all the 'foreign ideologies' that arise in Demons

4 In this passage, Bakhtin is discussing the underground man but he claims Stavrogin suffers from the same complex on p. 244. 
(Frank 1969, p. 668). As Dostoevsky says in the notebooks, 'In him lies the seed of the plot and the events of the novel.' (Dostoevsky 1968, p. 26). There is no root, origin, or basis for Stavrogin to repose upon (Ibid., pp. 44-45). He has a mother to whom he cannot say a single loving word, an absent father who dies in Stavrogin's youth, and a surrogate 'father' in Stepan, who Stavrogin no longer has a strong relationship with. As Dostoevsky says in the notebooks, 'He finds no solid basis within himself' (Ibid., p. 180). He therefore seeks to be his own basis.

In Dostoevsky's short story, Dream of a Ridiculous Man, the 'ridiculous man' dreams of the birth of self-consciousness in an innocent otherworldly people and we see the same contradictory desires for violence and for the pangs of conscience that characterized Stavrogin, appearing as a defining trait of self-consciousness:

They became acquainted with sorrow and came to love sorrow; they thirsted for suffering and said that Truth could only be attained through suffering [ ... ] When they became wicked, they started to talk about brotherhood and humaneness and understood these ideas. (Dostoevsky 2010, p. 354)

This is a significant parallel. The mythical, otherworldly people, once 'infected' with self-consciousness, are separated irrevocably from their previously innocent, Edenic state by the gulf of knowledge.

For Heidegger, the everyday experience of 'guilt' from one's conscience is grounded in a primordial 'guilt' subsisting within us (Heidegger 2007, p. 326). Primordial guilt names the guilt of having-to-exist in the first place. The guilt stems from the fact that they did not choose to be born, were not 'there' at the origin of their lives, but nonetheless must choose to live their unchosen lives. 'Although it has not laid that basis itself, it reposes in the weight of it, which is made manifest to it as a burden by Dasein's mood' (Ibid., p. 330).

Even though we can never go back to our birth and bring this basis of our being back into our power, we must be the basis. We must continue to make choices and exist, even though we are not the cause of ourselves. This 'not being there' disturbs us at our core; it is the fundamental not-ness, or guilt that all human beings must take up in existence.

For Neumann, Stavrogin's inability to believe in an absolute stems from his 'genuine liberalism'. Rather than seeking a revolution of morals, Neumann states that Stavrogin, possessed by a nihilism that recognizes the groundlessness of all things, apotheosizes the nullity of his own existence (Neumann 1993, p. 573). This is actually the nullity of not being the basis of one's own being, not being there at one's own birth. In his epiphany, he is being called upon to accept the burden of his null-origin, to avoid his deluded quest for exclusive self-origination.

Stavrogin wishes to achieve complete self-mastery by eradicating any sense of guilt within himself. This is why he engages in his heinous crime against Matryosha. He commits crimes in order to feel and overcome the moral guilt these acts engender in him. Stripping himself of dependence on others by becoming indifferent to their pain - he will give birth to himself anew as a man beyond human guilt and suffering. Matryosha's recurrent vision serves as a reminder to him that he can never completely overcome his guilt and be 'reborn' in this manner. It calls him to choose to live, perhaps to repent, and accept some meaningful narrative outside his empty willing.

In Heidegger, this choice comes from the future Self, calling the person who hears the call to a more authentic state of Selfhood (Heidegger 2007, pp. 320-21). The epistemological status of the Matryosha hallucination is unclear-Stavrogin believes that he conjures this memory volitionally but expresses doubts about this as well: 'You probably think that I' $m$ still doubtful and unsure whether it's me, and not actually a demon?' (Dostoevsky 2008, p. 757). In his written confession, he casts further doubt on the origin of his vision: 'It doesn't appear by itself; I myself summon it up and I can't help but summon it up, even though I simply can't live with it' (Ibid., p. 776). If we accept Stavrogin's insistence that the vision is a haunting 'memory' that he summons because 'this memory contains something that gratifies my [his] passions' (Ibid., p. 776), it could be argued that Matryosha's remembered image is an emanation of Stavrogin's perverse will to self-mastery, as he claims it to be, 
making the vision, in Heidegger's terms, a call stemming from Self to Self. However, the equivocation in his statements suggests that there is an element of this hallucination that is beyond his personal agency, though he struggles to admit this. In Bakhtinian terms, we could instead read this experience as the 'intersection of two consciousnesses in a single consciousness' which signals a fundamental feature present 'in every one of Dostoevsky's works' (Bakhtin 1984, p. 223). The obraz or image of Matryosha's shaking fist and her own separate and independent, silently admonishing 'voice' has penetrated into Stavrogin's soul in a painfully recurring form. This is significant as the call comes from beyond himself, but this is not the Self of exclusive Self-Mastery, as sometimes appears to be the case in Heidegger's vision. In fact, it is the obraz or silent speech of the other. It is a reminder that he cannot achieve full self-mastery, that he cannot be his own origin.

In the existential scheme of things, Stavrogin's epiphany gives him to understand the existentially necessary truth that all human beings are thrown into existence and can never be 'there' at their birth, yet must continue to be despite their null or unwilled origins. Thus, this epiphany provides Stavrogin with one aspect of the broader existential truth that we are the being between birth and death.

\section{Alyosha Karamazov}

Alyosha, the youngest Karamazov brother, is the voice of conscience for his family and is referred to as the novel's 'hero' (Dostoevsky 2003a, p. 1). He resides in a monastery at the beginning of the novel and is a favourite disciple of his mentor, Father Zosima, a compassionate and prophetic monk. Father Zosima's death leads Alyosha to almost lose his faith, but it is revived through an act of kindness from a character named Grushenka, and ultimately, through his epiphany.

At the beginning of the chapter, entitled 'Cana of Galilee', Father Paisii is keeping vigil over Zosima's body, reading aloud from the Gospels. This inspires a vision in Alyosha of the wedding at Cana. Malcolm Jones describes the scene as bearing all the hallmarks of what he, citing Epstein, calls a 'post-atheist, minimal religious experience, born of the irreconcilable clash between the light of faith and the darkness of unbelief' (Jones 2005, p. 80). Evidence for this lies in the latter part of the epiphany, which deals predominantly in elemental, naturalistic imagery. Alyosha is visited by several embodied forms of the ideal Other in his epiphany, but towards the end of the experience, the Other is simply heard, in a minimalistic and indeterminate fashion, as 'someone'.)

Connolly, writing in response to readings of the epiphany as 'nature mysticism', argues that critics have 'unnecessarily restricted their focus to the last moments of Alesha's experience [ ... ]' (Connolly 2007, p. 45). Perhaps this criticism equally applies to Jones. After all, the context of the epiphany and the appearance of an Other strongly associated with Christ are significant aspects of the experience. On the other hand, Thompson's intricate tripartite reading of the experience as a 'triptych' also suffers from an explicit overemphasis of the 'hierarchically superior centrepiece' (Thompson 1991, p. 294) of the epiphany, where the narration alternates between readings of the Gospel passage and Alyosha's inner speech.

Instead of overemphasising one particular sequence within the experience, it can be perceived as a process. The vision gradually strips itself of its doctrinal clothing, and lays bare essential kerygma in a minimalistic encounter between Alyosha and the essence of the religious. The essence of the religious, here, is our internal Other-relatedness, our sense of being-with and for the other. In Heideggerian terms, this internal Other-relatedness is designated by the existentiale of Mitsein, or 'Being-with'. 'Being-with' [Mitsein] is a fundamental existentiale for Heidegger. In this sense, the essence of the religious already subsists within every human's experience.

This capacity constitutes human beings as internally socialized Beings. 'Being-with' suggests an interconnectivity between oneself and the other, who is always present in the existentiality of every human experience, even when I am alone (Heidegger 2007, p. 157). 


\section{Being-With in Father Zosima's Teachings}

Although Heidegger recognized human beings as internally other-related in their existential experience, Levinas, Bakhtin, and Buber provided more expanded specifications of what 'Being-with' entails. ${ }^{5}$ Bakhtin theorizes the origin of consciousness, reformulating the Cartesian cogito ergo sum, the 'I think, therefore I am', as the et ego sum, or the 'I, too, exist' (Bakhtin 1993, p. 40. For Bakhtin, it is the response to the otherness of the other, rather than the self-subsistence of my own rational subjectivity, that shapes the self. The ' $\mathrm{I}$, too, exist' is a response ensuring our radical singularity and answerability for our actions and demonstrating the uniqueness of other respondents in my world. Recognizing my inner other-relatedness, my ethical goal becomes not simply to express myself, but to express my response to the Other.)

We can also find such reflection on 'Being-with' in Brothers Karamazov, specifically in the teachings of Father Zosima.

Once, in the infinity of existence unmeasurable by time or space, a spiritual creature, upon its appearance on earth, is given the power to say: 'I am and I love'. Once, and only for a moment, is that creature given the knowledge of active, living love, and this is why that creature was given life on earth, and with it, time and space. (Dostoevsky 2003a, p. 432)

Zosima's statement implies that at the origin of human consciousness is a being fulfilled, recognizing itself in its active, living love for others. A prominent ethical axiom recurrently emerging in Zosima's final teachings states that 'every one of us is answerable for everyone else and for everything' (Ibid., p. 384). The axiom is associated with a range of epiphanies: Zosima, his brother Markel, Dmitry Karamazov, Alyosha and others all give expression to our complete ethical responsibility to the Other. It is perhaps the central tenet of Zosima's ethics. Zosima advises listeners to love persons in their sin, recommending this as the form of love most resembling God's love, and the highest possible form of love on earth. The ethical individual must not first demand the repentance of the sinner; their endorsement of his/her ethic and then offer warmth, but instead, one must take on the sins of the unrepentant sinner without further qualification:

'Love man in his sin too, for such love resembles God's love, the highest possible form of love on earth. Love God's creation, love every atom of it separately, and love it also as a whole; love every green leaf, every ray of God's light; love the animals and the plants and love every inanimate object. If you come to love all things, you will perceive God's mystery inherent in all things'. (Ibid., pp. 426-27)

Taken together, these teachings set forth the ontological nature and radical ethical demand issuing from our inner other-relatedness. This is precisely what Alyosha is given to understand.

Alyosha's epiphany possesses all four of James' traits—transiency, ineffability, passivity, and noetic understanding. It is what Miller and James would call a 'conversion' experience (Miller 2003, p. 33). His new noetic understanding results in a transformation of his life: 'He was a weak youth when he fell on the ground and he rose a strong and determined fighter. He knew it. He felt it during that moment of rapture.' (Dostoevsky 2003a, p. 486)

The experience begins with Alyosha drifting into a trance-like state, where his feelings keep displacing one another 'smoothly in a sort of quiet, harmonious rotation.' He approaches his dead mentor's body and fragments of thoughts flash through his mind 'like little sparks' all apparently 'part of something continuous, of a greater whole ... ' (Ibid., pp. 481-82). His thoughts come to an initial climax.

5 Dostoevsky's leitmotif of 'each person being responsible for all' becomes a fundamental axiom in Lévinas' existential phenomenology (Lévinas 1985, p. 22). 
'It wasn't sorrow, it was human happiness that Christ extolled, and the first miracle He worked was to bring men happiness ... 'He who loves men loves their happiness,' Father Zosima used to repeat so often-that was one of his guiding ideas ... ' (Ibid., p. 483)

At this stage, the epiphany is a prefiguration of the Christian narrative of the miracle at the marriage feast in Cana. However, the setting is not the centrally significant religious aspect to the epiphany. Instead, it is the essential kerygma at the heart of Christ and Zosima's teachings-one's desire to bring about the happiness of one's fellow human beings-in other words, one's Being-for-the-Other.

Alyosha's vision of the wedding expands. Father Zosima appears to have a seat at the table. He rises and comes to Alyosha. The narrative deviation is signalled by the statement, 'How was it that he too had been invited to the wedding at Cana of Galilee?' Zosima answers that he was 'bidden'. Thus, Alyosha's epiphany is already dialogic in nature, and involves a visitation by an Other, whom he loves more deeply than any other in the world. Zosima asks Alyosha, 'Can you see Him?' Who 'He' is remains unclear but can be presumed to be Christ. ${ }^{6}$

'He is [ ... ] infinitely merciful and, out of love, He has made Himself like one of us and shares our joy and turns our water into wine, so that the joy of the guests shall not cease, and He invites more and more guests, unceasingly, more new guests forever and ever.' (Ibid., pp. 484-85)

We can already see the repetition of the leitmotif of loving the happiness of one's fellow human being. He is said to be 'like one of us' insofar as 'he shares our joy' of bringing joy to others. This suggests both that Christ is like us insofar as we are for-the-Other internally, and that we imitate the ideal of Christ insofar as we strive to be for the Other. Thus, while this is a Christian epiphany, it need not be as exclusively Christian, since its essential message is also found at the heart of many other religions.

Alyosha returns to the coffin and the real world, and his epiphany, still not complete, begins to take on more of the minimalist traits Jones identified. Instead of an embodied vision, he simply hears his dead elder's voice commanding him. Alyosha appreciates the beauty of the natural world in all its singularities, and hugs and kisses the earth in a state of ecstasy and rapture. Then, once again, 'a voice rang out in his soul.' This time, it is not Zosima's. The voice tells him to wet the earth with the tears of his joy.

'It was as if the threads of all those innumerable worlds of God had met in his soul and his soul was vibrating from its contact with "different worlds." He craved to forgive everyone and everything and to beg for forgiveness-oh, not forgiveness just for himself, but for everyone and everything. "Others will ask forgiveness of me too," the voice rang out in his soul again.' (Ibid., p. 486)

Thus, the epiphany ends with Dostoevsky's fundamental leitmotif. It is also possible to see Jackson's ethic of striving towards an ideal sense of love and goodness, which is contrary to our human nature, in other words, striving to be other than ourselves, in Alyosha's moment here (Jackson 1978, Preface, p. $\mathrm{x})$. This is the essential ethical content of human nature in Dostoevsky's fiction.

Despite the consistently changing settings and embodied forms of the visitors that come to Alyosha, this meaning remains a constant presence throughout the epiphany and, as is manifest

6 Paul Fung reaches some surprising conclusions about this figure. He argues that the 'someone' who visits Alyosha during his epiphany is his debauched father, Fyodor Karamazov. Fung's claim is based entirely on the detail that Alyosha's epiphanic vision takes place in a banquet. He states that this is a 'carnivalesque detail of the dream' and parallels what would happen 'in an orgy organized by Alyosha's other father, that is, the old Karamazov.' (Fung 2015, p. 123) Thus, he concludes that the father figure in the vision actually stands for three of Alyosha's 'fathers', 'Zosima, Christ, and the Old Karamazov.' (Ibid., p. 5) This allows him to state that the vision is ambivalent, containing both the divine and the debauched within it. Of course, anyone familiar with Alyosha's vision would balk at the absurdity of this conclusion. The vision occurs as Alyosha is mourning the death of his mentor, the Holy Father Zosima, who is most closely associated with the living spirit of Christ. There is no sense of debauchery, villainy, or cynicism in the vision at all, and it is possibly the most unambiguously sacred, or filled with the spirit of the love of the earth, of Dostoevsky's epiphanies. 
in the leitmotif-constitutes the essential noetic understanding given to Alyosha at the close of the experience-of desiring to 'forgive everyone and everything'. Alyosha's experience is a primordial encounter of a fundamental aspect of human nature, our existentially necessary constant inner dialogism, our sense of 'Being-with'. It builds onto this existentiale a moral imperative to be for-the-Other completely and utterly. Thus, Alyosha experiences the ontological meaning and ethical demand issuing from our internal other-relatedness in his epiphany.

\section{Leaping-Forth into Death: Kirillov}

Jones recognizes that it is the 'silence at the core of the apophatic religion', that is, the silence in an epiphanic moment, that allows for such a variety of meanings. This silence can be

interpreted or experienced either as a fullness or as an absence, as glorious plenitude or as desolate abyss, as a God-centred locus of meaning or as total chaos and meaninglessness. (Jones 2005, p. 71)

Characters in Dostoevsky live 'on the cusp of the fullness of faith and the abyss of nothingness' (Ibid., p. 92). Peering over this ambivalent threshold, Alyosha experiences the fullness of one's being-for-the-Other. However, epiphany allows for much darker-although no less true-revelations of primordial reality. It is in this realm of 'total chaos and meaninglessness', staring catatonically into an 'abyss' of nothingness, that Kirillov in Demons comes face to face with the possibility of his own death and nullity.

\subsection{Authentic and Inauthentic Being-Towards-Death in Heidegger}

According to Heidegger, in everyday life, human beings fear death as if it were an oncoming event, rather than a process that we are constantly undergoing. People we do not know are dying by the second all over the world. We encounter them as myriad events or 'case[s] of death' (Heidegger 2007, p. 297) occurring out of sight. We see death in our lives constantly as well—strangers, neighbours, acquaintances, family members (Ibid.). Since death is clearly around us and we live with an understanding that we will die, human beings seek to evade the responsibility of their mortality, and understand death as an infinitely postponed event that has nothing to do with them.

Humans express their evasion in phrases such as 'One of these days one will die too, in the end; but right now it has nothing to do with us' and 'one dies' (Ibid.). Such talk allows humans to conceal their mortality from themselves. 'Idle talk', 'curiosity', 'ambiguity' and the way death has been publicly interpreted as something that will happen 'sometime, but not right away' (Ibid., p. 299) allow humans to forget the truth about the constant possibility of their own death.

Humans are always oriented towards-death, either in an inauthentic everyday 'fleeing in the face of death' (Ibid., p. 298) or in an authentic relation to death possible with the appropriate mood, which, for Heidegger, is 'anxiety' (Ibid., p. 231). What threatens in anxiety is not some specific possibility or 'potentiality-for-Being' that may or may not occur. The world and its social and practical involvements 'has the character of completely lacking significance' (Ibid.). People are unable to absorb themselves in their everyday possibilities. In anxiety, Heidegger states, one confronts the possibility of the impossibility of engaging with the world. Without any entity to distract their attention, oppressed by an indefinite threat to their Being, the subject experiences the possibility of the nothingness of nonexistence. Anxiety discloses the possibility of death.

\subsection{Kirillov's Epiphany}

Dostoevsky's Demons can be read as a catalogue of existential responses to knowledge of mortality. Most characters seek to evade their sense of mortality through gossip, rumour, and idle talk. A particularly pertinent example takes place when a group of young revellers known as the 'scoffers' entertain themselves by adopting a frivolous and distracted attitude towards a young suicide's corpse (Dostoevsky 2008, p. 364). 
Almost every character in Demons is conditioned by fear, especially of the pain of death. I will only mention three moments of significant fears related to death: Marya Lebyadkina's prophetic 'stark terror' (Ibid., p. 302) when she is visited by Stavrogin, the man who ultimately sanctions her murder; Lyamshin's 'unnatural scream' (Ibid., p. 670) when disposing of Shatov's corpse, which is specifically discussed by the narrator as a 'powerful moment of fear'; and Liputin's 'jolt' (Ibid., p. 624) of fear, when he realizes that Pyotr Verkhovensky was involved in Fedka's murder. This causes him to fear for his own life if he disobeys Pyotr's orders. ${ }^{7}$

By contrast, Kirillov, in planning his suicide, actively seeks near-death intensity. Kirillov's experience of authentic being-towards-death in a moment of epiphany aims to prove the possibility of liberating humanity from their addiction to pain and fear. 'I want to take my life because that's my idea, because I don't want to be afraid of death ... ' (Ibid., p. 415). Whereas for Heidegger, one can experience the pure nothingness of death in anxiety, Kirillov believes one can only have such an epiphanic moment, if one wills one's own death. 'There are moments, you reach moments, and time suddenly stops and it will become eternal' (Ibid.).

Peace recognizes that Kirillov is seeking a 'state of mystical timelessness, an eternal present' (Peace 1971, p. 185). Kirillov, like Stavrogin, is an intensity addict (De Jonge 1975, pp. 123-25). He wishes to overcome the limits of his own finitude, if only for an instant, through an immanent experience of transcendence. This experience is the summum bonum of his life.

There are seconds-they come only five or six at a time-when you suddenly feel the presence of an eternal harmony that has been fully attained. This is not something earthly. I'm not saying that it's heavenly, but that man in his earthly form cannot endure it. He must change physically or else die. It is a clear and unambiguous feeling. It's as if you suddenly have a sense of nature as a whole, and you suddenly say: yes, this is true. God, when he was creating the world, said at the end of each day of creation: 'Yes, this is true, this is good.' This ... this is not deep emotion, but is simply joy. You don't forgive anything, because there's no longer anything to forgive. You don't really love-oh, this is higher than love! If it lasts longer than five seconds, your soul can't endure it and must disappear. In these five seconds I live an entire lifetime, and for them I will give my entire life, because it's worth it. (Dostoevsky 2008, p. 653)

Dostoevsky reportedly had such epiphanic episodes during epileptic seizures (Rayport et al. 2011, p. 558; Rice 1985, p. 111) and Prince Myshkin in The Idiot gives testimony to this type of experience (Dostoevsky 2003b, p. 245.) Although Kirillov expects a feeling of 'simple joy', his epiphany is far from a blissful one. Pyotr Stepanovich, the leader of a revolutionary band, is present during Kirillov's moment of epiphany. Aware of Kirillov's suicidal intent, Pyotr persuaded Kirillov to sign a suicide note confessing to various crimes, which Pyotr planned. Pyotr wishes to ensure that Kirillov does not renege on his deal. He picks up his revolver and runs into the next room. Not hearing a shot confirming Kirillov's demise, Pyotr picks up a candle and walks into the adjacent room in search of him. He finds him standing in the corner.

'What struck him most of all was that the figure, despite his shouts and his furious attack, hadn't even stirred, hadn't moved a single limb, as though it were made of stone or wax. The pallor of the face was unnatural, the black eyes were completely fixed and were staring at some point in space'. (Dostoevsky 2008, p. 691)

The description suggests emptiness and nothingness instead of fullness and abundance. This is Kirillov's moment, where he comes face to face with the possibility of his own nothingness, of death.

7 Son of Stepan, Pyotr Verkhovensky is a duplicitous and scandal-mongering violent revolutionary leading a band of characters towards various acts of mischief and chaos throughout the novel. He has a dialogic exchange with Kirillov before his epiphany. 
Once Pyotr draws close, Kirillov bites him, putting Pyotr into a frenzied panic as he flees the room. It is only then that Kirillov, returning to himself, is able to commit his will to suicide. 'Now, now, now ...' (Ibid., p. 691) he says before the gunshot is heard ringing out. The repeated imperative suggests that Kirillov, after his moment of primordial nothingness, has taken power over his own will and commanded himself to commit suicide.

Paperno notes that Kirillov 'dies not as a man-god but as a madman, howling, kicking, and biting' (Paperno 1997, pp. 158-59). Anderson has suggested that this implies that Kirillov has descended to a 'subhuman' (Anderson 1997, p. 120) animality. Yet animals do not generally commit suicide. The epiphany gives him a primordial insight into the essentially human-our directedness-towards-death and the unfathomable nullity of death itself. This act of will obviously does not lead to him emerging a new man. He does not change physically but dies just as any other person would. However, many commentators recognize that Kirillov, who lives on Bogoyavlenskaya or 'epiphany' street, does have an experience of numinous intensity, though one filled with terror and violence (Anderson 1997, p. 120; Jones 1976, p. 151; Williams 2012, pp. 89-90).

Does Kirillov have an epiphany? Kirillov's experience does share at least three of the four traits of epiphanic experiences I identified earlier-transiency, passivity, ineffability; the fourth trait, "noetic quality' is more difficult to pin down.

With regards to what Kirillov is given to understand about mortality in his epiphany, it is important to note two things. First, Kirillov already explicitly possesses a special understanding of the existential nature of being-towards-death, and how people seek to evade this responsibility out of the fear of pain:

Life is pain, life is fear and man is unhappy. Now all is pain and fear. Now man loves life because he loves pain and fear [ ... ] In the stone there's no pain, but in the fear of the stone there is pain. [This is a reference to a hypothesis Kirillov poses on the previous page-a man crushed by a large stone will not feel pain, but 'while it's hanging, you'll be very much afraid that it will be painful.'] God is the pain of the fear of death. Whoever conquers pain and fear will himself become God. Then a new life, then a new man, everything new ... . (Dostoevsky 2008, p. 128)

After the epiphany, Kirillov utters only three self-directing words, 'Now, now, now'. These words can suggest at least two interpretations. The epiphany is either an affirmation of the present. It constitutes an attempt to give expression to the 'state of mystical timelessness [ ... ] eternal present' (Peace 1971, p. 185) Kirillov wishes for. However, Kirillov's experience is certainly not a moment filled with 'simple joy', as he expected. His violent attack on Pyotr and his desire to draw a spiteful face on his false confession letter indicate that his experience is not an 'affirmation' as such. Instead, it appears to be an experience of primordial nullity stemming from his peculiar relation to death. In this case, nullity is what he is given to understand. In correlating it with the core traits of epiphany, we can conclude that Kirillov does have an epiphany, even if it is one filled with chaos and meaninglessness, rather than fullness and joy.

The experience is something that 'man in his earthly form cannot endure'. Two possible interpretations stem from here. Either Kirillov, after experiencing the inexperienceable nullity of non-being, shoots himself, expecting to conquer death and shed the limitations of his earthly form, in order to become a 'Man-God' as he prophesizes, or the experience fills him with an overflowing terror. He cannot endure an experience of this deathly abyss and, thus overwhelmed, he kills himself.

Carol Apollonio, who recognizes that there are moment of apophasis in Dostoevsky's novels where characters experience a 'feeling of a supernatural fullness of being, which rends the heart and blinds the mind' (Apollonio 2009, p. 6), opposes the virtuous apophatic experiences that exceed logical description to all the seemingly 'demonic' characters in Dostoevsky who exist as 'a single shared consciousness' and use logic and linguistic argument to prove their metaphysical positions (Ibid., p. 9). This dichotomy cannot account for Kirillov's 'apophatic' experience. Kirillov's experience also 'rends the heart and blindsthe mind', but instead of signalling the 'feeling of a supernatural fullness of being', points to a feeling 
of complete emptiness or nothingness. This is because apophasis implies a realm more fundamental than everyday morality and can contain either overflowing fullness or all-consuming nothingness. In both cases, such experiences are approached through 'faith' in one's deepest metaphysical beliefs, and point to an overpowering reality beyond language and conventional logical proof. Kirillov appears to encounter a potentially 'demonic' realm of nothingness. It is clear that Kirillov does experience something otherworldly in this moment, even if that something is nothing at all.

Whereas Stavrogin's epiphany reveals his inability to get beyond his birth, Kirillov's contradictory desire to live through a moment of death leads to an experience of pure nothingness, a moment that he cannot ultimately endure. The epiphanies in Dostoevsky's fiction reveal humanity in the space of their radical finitude—as the beings between birth and death.

\section{Conclusions}

At the beginning of this article, I rooted Dostoevsky's existentialism in two primary principles. First, that 'existence precedes essence' and, secondly, by correlating 'ecstatic epiphanies' with the existential phenomenological method of cataloguing ways in which human beings can primordially experience the constitutive features of existence.

I have demonstrated the second correlative principle at work in the fiction by presenting interpretations of various 'ecstatic epiphanies' in two of Dostoevsky's major novels, Demons and Brothers Karamazov. But the fact that this article has not had space to cover even all the epiphanies occurring in these two novels alone demonstrates how commonplace this phenomenon is in Dostoevsky.

The point regarding the first principle 'existence precedes essence' has also been made insofar as I have focused on how truth occurs in lived experience during moments of epiphany, and not in universally valid propositions uttered by characters nor in any 'idea in itself' divorced from the carrier of that idea. Thus, I have sought to demonstrate how Jackson's recognition of the human ethical relation to the ideal is certainly operative in Dostoevsky, but only as it appears as striving towards the ideal. No character can ever be certain of the truth of their vision of an ideal reality; they can only approach it with a sense of faith in their convictions and intuitions. Humans are always, necessarily, the beings between birth and death in these novels. This is why the 'fantastic' always appears within a realist discourse in the major novels, i.e. we are never really sure whether the visions, hallucinations, dreams indicate a transcendent realm, or are simply a manifestation of the character's own deepest ideas and, often, illnesses. In this sense, Bakhtin is correct in saying of Dostoevsky that,

'His hero was a man, and in the final analysis he represented not the idea in man, but (to use his own words) the 'man in man.' The idea for him was ... a form for revealing it [the man in man], or-and this is the last and most important—a 'medium,' an environment in which human consciousness could be revealed in its deepest essence ... Dostoevsky neither knows, nor perceives, nor represents the 'idea in itself' in the Platonic sense, nor 'ideal existence' as phenomenologists understands it. For Dostoevsky there are no ideas, no thoughts, no positions which belong to no one, which exist 'in themselves'. (Bakhtin 1984, p. 31)

Bakhtin's Dostoevsky makes possible an authentically existential reading of Dostoevsky, not simply rooted in a banal or superficial existentialism, but committed to the lived experience of truth, the embodied idea, and the revelation of human existence.

Moments of epiphany reveal only the possibility of the transcendent truth of a particular character's fundamental driving idea. However, these moments do reveal necessary truths about the conditions of human existence in immanent reality, in the space between birth and death. These various conditions manifest another fundamental Bakhtinian notion, the 'possibility of simultaneous coexistence' (Ibid., p. 29). The variety of truths, about our primordial conscience, our internal-other-relatedness or sense of being-with, or our being-towards-death all coexist simultaneously in human experience. Since there is no existential-ontological hierarchy 
between these existentialia - they are equiprimordial in the human constitution-ecstatic epiphanies manifest the "unification of highly heterogeneous and incompatible material—with the plurality of consciousness-centres not reduced to a single ideological common denominator' (Ibid., p. 17). This is Bakhtin's definition of polyphony (Ibid.). In 'ecstatic epiphany', characters can live through a huge span of time, as the ridiculous man and Stavrogin do in their dreams, or Ivan Karamazov does in his encounter with the devil, or perhaps even as Kirillov does in his muted epiphany. In immanent chronological time, these epiphanies may only last for a few moments or perhaps slightly longer in dream visions. The 'timelessness' of the epiphanies also correlates well with Bakhtin's notion. Thus, although these epiphanies are varied and span different novels, they can all be said to simultaneously coexist, both in the space of epiphanic timelessness, and in the human constitution itself.

Funding: This research received no external funding.

Conflicts of Interest: The author declares no conflict of interest.

\section{References}

Anderson, Nancy K. 1997. The Perverted Ideal in Dostoevsky's 'The Devils'. New York: Peter Lang.

Apollonio, Carol. 2009. Dostoevsky's Secrets: Reading against the Grain. Evanston: Northwestern University Press.

Bakhtin, Mikhail. 1984. Problems of Dostoevsky's Poetics. Translated by Caryl Emerson. Minneapolis: University of Minnesota Press.

Bakhtin, Mikhail. 1993. Towards a Philosophy of the Act. Translated by Michael Holquist, and Vadim Liapunov. Austin: University of Texas Press.

Berdyaev, Nicholas. 1957. Dostoevsky. Translated by Donald Attwater. New York: Meridian Books.

Coetzee, John Maxwell. 1985. Confession and Double Thoughts: Tolstoy, Rousseau, Dostoevsky. Comparative Literature 37: 193-232. [CrossRef]

Connolly, Julian. 2007. Dostoevskij's Guide to Spiritual Epiphany in Brothers Karamazov. Studies in East European Thought 59: 39-54. [CrossRef]

De Jonge, Alex. 1975. Dostoevsky and the Age of Intensity. London: Secker \& Warburg.

Dostoevsky, Fyodor. 1968. The Notebooks for The Possessed. Translated by Victor Terras. Chicago: University of Chicago Press.

Dostoevsky, Fyodor. 1994. A Writer's Diary, Vol 1. 1873-1876. Translated by Kenneth Lantz. Evanston: Northwestern University Press.

Dostoevsky, Fyodor. 1997. Winter Notes on Summer Impressions. Translated by David Patterson. Evanston: Northwestern University Press.

Dostoevsky, Fyodor. 2001. Notes from the Underground. Translated by Michael Katz. New York: W.W. Norton \& Company. Dostoevsky, Fyodor. 2003a. The Brothers Karamazov. Translated by Andrew MacAndrew. New York: Bantam.

Dostoevsky, Fyodor. 2003b. The Idiot. Translated by Anna Brailovsky based on Constance Garnett translation. New York: Random House.

Dostoevsky, Fyodor. 2008. Demons. Translated by Robert A. Maguire. London: Penguin Books.

Dostoevsky, Fyodor. 2010. The Gambler and Other Stories. Translated by Ronald Meyer. St. Ives: Penguin Classics. Frank, Joseph. 1969. The Masks of Stavrogin. The Sewanee Review 77: 660-91.

Fung, Paul. 2015. Dostoevsky and the Epileptic Mode of Being. London: Legenda.

Heidegger, Martin. 2007. Being and Time. Translated by Macquarrie Johnand Robinson Edward. Oxford: Blackwell Publishing.

Jackson, Robert Louis. 1978. Dostoevsky's Quest for Form: A Study of His Philosophy of Art. Bloomington: Physsardt Publishers.

James, William. 1982. The Varieties of Religious Experience. London: Penguin Books.

Jones, Malcolm. 1976. Dostoyevsky: The Novel of Discord. London: Elek.

Jones, Malcolm. 1983. Dostoevsky, Rousseau and Others. Dostoevsky Studies 4: 81-94.

Jones, Malcolm. 2005. Dostoevsky and the Dynamics of Religious Experience. London: Anthem Press.

Kaufmann, Walter. 2004. Existentialism from Dostoevsky to Sartre. New York: Plume.

Lévinas, Emmanuel. 1969. Totality and Infinity; an Essay on Exteriority. Translated by Alphonso Lingis. Pittsburgh: Duquesne University Press. 
Lévinas, Emmanuel. 1985. Ethics and Infinity: Conversations with Philippe Nemo. Translated by Richard Cohen. Pittsburgh: Duquesne University Press.

Lossky, Vladimir. 2005. The Mystical Theology of the Eastern Church. Cambridge: James Clarke \& Co.

McDonald, Matthew G. 2008. The Nature of Epiphanic Experience. Journal of Humanistic Psychology 48: 89-115. [CrossRef]

Miller, Robin Feuer. 2003. Adventures in Time and Space: Dostoevsky, William James, and the Perilous Journey to Conversion. In William James in Russian Culture. Edited by Joan D. Grossman and Ruth Rischin. New York: Lexington Books.

Neumann, Harry. 1993. Responsible and Irresponsible Liberalism: Dostoevsky's Stavrogin. History of European Ideas 164: 569-75. [CrossRef]

Paperno, Irina. 1997. Suicide as a Cultural Institution in Dostoevsky's Russia. Ithaca: Cornell University Press.

Peace, Richard. 1971. Dostoyevsky: An Examination of the Major Novels. Cambridge: Cambridge University Press.

Rayport, Shirey M. Ferguson, Mark Rayport, and Carolyn A. Schell. 2011. Dostoevsky's Epilepsy: A New Approach to Retrospective Diagnosis. Epilepsy \& Behavior 22: 557-70.

Rice, James. 1985. Dostoevsky and the Healing Art: An Essay in Literary and Medical History. Ann Arbor: Ardis Publishers.

Rollberg, Peter. 2014. Mastermind, Terrorist, Enigma: Dostoevsky's Nikolai Stavrogin. Perspectives on Political Science 43: 143-52. [CrossRef]

Shestov, Lev. 1969. Dostoevsky, Tolstoy and Nietzsche. Translated by Spencer Roberts. Athens: Ohio University Press. Smart, Ninian. 1984. The Religious Experience of Mankind. New York: Scribner.

Thompson, Dianne. 1991. The Brothers Karamazov and the Poetics of Memory. Cambridge: Cambridge University Press. Williams, Rowan. 2012. Dostoevsky: Language, Faith, and Fiction. Waco: Baylor University Press.

(C) 2019 by the author. Licensee MDPI, Basel, Switzerland. This article is an open access article distributed under the terms and conditions of the Creative Commons Attribution (CC BY) license (http:/ / creativecommons.org/licenses/by/4.0/). 